\title{
EKSPRESI PROTEIN p53 PADA KULTUR SEL FIBROBLAS GINGIVA YANG DIPAJAN LIPOPOLISAKARIDA BAKTERI GRAM-NEGATIF
}

\author{
Banun Kusumawardani ${ }^{\star}$, Totok Utoro ${ }^{* *}$, Al Supartinah $\mathrm{S}^{\star \star \star *}$ \\ * Bagian Periodontologi Fakultas Kedokteran Gigi Universitas Jember \\ ** Bagian Patologi Anatomi Fakultas Kedokteran Universitas Gadjah Mada \\ *** Bagian Biologi Oral Fakultas Kedokteran Gigi Universitas Gadjah Mada
}

Banun Kusumawardani, Totok Utoro, Al Supartinah S. Ekspresi protein p53 pada kultur sel fibroblas gingiva yang dipajan lipopolisakarida bakteri gram-negatif. Indonesian Journal of Dentistry 2005; 12(3):128-131.

\begin{abstract}
Bacterial lipopolysaccharide (LPS) is implicated in the etiology of inflammatory periodontal disease. Aside from immunopathologic reactions which may be involved in the pathogenesis of the disease, the possibility exist that direct cytotoxic effect on cultured human gingival fibroblasts may be equally destructive. The expression of $\mathrm{p} 53$ protein can be one of markers to examine the state of impaired DNA. The purpose of this study was to investigate the effect of LPS toward expression of $\mathrm{p} 53$ protein on cultured human gingival fibroblasts. Cultured human gingival fibroblasts were exposed to LPS in concentrations of 50 and $200 \mu \mathrm{g} / \mathrm{ml}$ and untreated medium for a period of 24 and 48 hours. Cells were harvested and prepared for immunohistochemical evaluation. After exposure for 24 hours, the fraction of p53-positive cells was $81.7 \%$ in case of $50 \mu \mathrm{g} / \mathrm{ml} \mathrm{LPS}$, and $88.8 \%$ in case of $200 \mu \mathrm{g} / \mathrm{ml} \mathrm{LPS}$. After exposure for 48 hours, the fraction of p53positive cells was $32.2 \%$ in case of $50 \mu \mathrm{g} / \mathrm{ml} \mathrm{LPS}$, and $21.1 \%$ in case of $200 \mu \mathrm{g} / \mathrm{ml} \mathrm{LPS}$. None of untreated group showed p53-positive cells. Up-regulation of p53 protein during the initial logarithmic phase of growth may be a consequence of on-going DNA damage.
\end{abstract}

Keywords: bacterial lipopolysaccharide; gingival fibroblast; p53 protein.

\section{Pendahuluan}

Agen primer etiologi penyakit periodontal adalah perlekatan plak gigi yang mengandung mikroorganisme dan produknya pada permukaan gigi.' Mikroorganisme tersebut tidak hanya mampu menimbulkan respon imun inang dan berhubungan dengan produksi berbagai agen perusak jaringan, ${ }^{2}$ tetapi juga menghasilkan endotoksin atau lipopolisakarida (LPS). Walaupun LPS merupakan agen inflamatorik yang kuat dan berperan penting pada penyakit periodontal inflamatorik, tetapi LPS juga mempunyai efek sitotoksik secara langsung pada sel-sel periodonsium. ${ }^{3,4}$

Lipopolisakarida dari berbagai bakteri gramnegatif mempunyai kapasitas yang mirip untuk menghambat pertumbuhan fibroblas gingiva manusia. $^{5}$ Pajanan LPS dengan konsentrasi 100 sampai $1000 \mu \mathrm{g} / \mathrm{ml}$ dan waktu pajanan sampai 7 hari pada kultur sel fibroblas tikus dapat menurunkan 
pertumbuhan dan viabilitas sel, ${ }^{3}$ tetapi Takata $\mathrm{dkk}^{6}$ mendapatkan sel junctional epithelium tikus dapat memulai siklus sel untuk berproliferasi setelah dipajan LPS dengan konsentrasi $5 \mathrm{mg} / \mathrm{ml}$ selama 1 hari.

Pajanan bahan yang bersifat sitotoksik dapat mengakibatkan kematian dan kerusakan sel. Untuk mencegah akibat yang tidak diinginkan, sel mempunyai metode untuk mendeteksi kerusakan DNA dan tindakan bunuh diri. ${ }^{7}$ Kerusakan DNA tersebut dapat dideteksi oleh protein p53. Setelah protein p53 menghentikan siklus sel maka kerusakan diperbaiki atau dapat memicu apoptosis. Protein p53 berinteraksi dengan sejumlah besar protein sel dan berintegrasi dengan banyak sinyal yang mengontrol hidup dan mati sel. ${ }^{8}$

Penelitian tentang aksi LPS tersebut merupakan hal-hal pokok untuk klarifikasi mekanisme aktivitas LPS. Penelitian ini bertujuan untuk mendapatkan data tentang perbedaan pengaruh pajanan LPS konsentrasi 50 dan $200 \mu \mathrm{g} / \mathrm{ml}$ dengan waktu pajanan 24 dan 48 jam pada kultur sel fibroblas gingiva manusia terhadap ekspresi protein $\mathrm{p} 53$.

\section{Bahan dan Cara Kerja}

\section{Prosedur Kultur Primer Sel Fibroblas Gingiva Manusia}

Jaringan gingiva diambil dari gingiva bebas pada gigi P1 untuk perawatan ortodontik yang sudah diekstraksi. Pasien sehat, tanpa gejala klinis inflamasi atau hiperplasi gingiva, tanpa riwayat penyakit sistemik, dan tidak merokok.

Jaringan gingiva dicuci tiga kali dengan PBS yang mengandung penicillin dan streptomycin untuk menghindari kemungkinan kontaminasi bakteri. Jaringan gingiva dipotong-potong berukuran sekitar $1 \mathrm{~mm}^{3}$ dan ditutup deckglass. Diberi $5 \mathrm{ml}$ media kultur dan diinkubasi ke dalam inkubator $\mathrm{CO}_{2} 5 \%$, $37{ }^{\circ} \mathrm{C}$ selama 3 hari. Eksplan jaringan gingiva dipindahkan dari petri dish. Media kultur diganti hingga pertumbuhan sel mencapai konfluensi yang memungkinkan untuk dipasase (subkultur).

\section{Prosedur pembuatan sampel untuk metode imunohistokimiawi}

Suspensi sel fibroblas yang mengandung sekitar $2 \times 10^{5} \mathrm{sel} / \mathrm{ml}$ dipindahkan ke dalam 24 multiwell plate, kemudian diberi media kultur. Setelah diinkubasi selama 48 jam, media kultur dibuang. Sel fibroblas diberi $1 \mathrm{ml}$ media kultur yang mengandung LPS Escherichia coli dengan konsentrasi 50 dan $200 \mu \mathrm{g} / \mathrm{ml}$. Sumuran tanpa perlakuan sebagai kontrol hanya diberi media kultur. Setelah diinkubasi selama 24 dan 48 jam, sel-sel fibroblas dipisahkan dengan trypsin dan dipindahkan ke dalam mini tube, selanjutnya dilakukan sentrifugasi selama 10 menit. Suspensi sel diteteskan pada slide poly-L-lisin dan dikeringkan pada suhu kamar. Fiksasi dengan methanol PA, kemudian aseton PA. Sediaan kemudian diaplikasi dengan hidrogen peroksida $0,5 \%$ dalam methanol absolut selama 10 menit, untuk mengakhiri aktivitas endogenous peroxidase. Aplikasi dalam normal serum, kemudian diaplikasi antibodi primer dengan dilusi 1:100 untuk p53. Inkubasi selama semalam pada $4^{\circ} \mathrm{C}$. Inkubasi dalam biotinylated secondary antibody, kemudian diinkubasi dalam streptavidine peroxidase. Setiap tahap dicuci dengan PBS $2 \times 5$ menit. Aplikasikan DAB dan cuci pada air mengalir selama 15 menit. Counterstained dengan Harry's hematoxylin. Mounting dengan Canada balsam dan sediaan ditutup dengan deckglass. Lihat dibawah mikroskop cahaya dengan pembesaran 400x. Hitung semua sel, baik yang terekspresi atau tidak pada 5 lapang pandang. Inti sel yang terekspresi protein $\mathrm{p} 53$ berwarna coklat. Hasil penghitungan sel dikonversikan menjadi persentase ekspresi p53.

\section{Analisis Data}

Uji statistik Oneway ANOVA digunakan untuk mengetahui perbedaan pengaruh yang ditimbulkan antar kelompok berdasarkan konsentrasi dan waktu pajanan, dengan tingkat kemaknaan $\mathrm{p}<0,05$. Jika terdapat perbedaan yang signifikan, dilanjutkan dengan uji LSD untuk mengetahui signifikansi perbedaan dalam kelompok. Uji statistik Univariate ANOVA digunakan untuk mengetahui interaksi antara kelompok konsentrasi dan waktu pajanan.

\section{Hasil}

Ekspresi protein p53 dapat dilihat pada Gambar 1 dan 2. Kultur sel fibroblas gingiva pada kelompok kontrol (Gambar 1) memperlihatkan semua inti sel fibroblas gingiva tidak berwarna coklat. Hal tersebut menunjukkan bahwa tidak terjadi kerusakan DNA pada kelompok kontrol. Kultur sel fibroblas gingiva pada kelompok perlakuan konsentrasi LPS 50 dan $200 \mu \mathrm{g} / \mathrm{ml}$ dengan waktu pajanan 24 dan 48 jam, memperlihatkan ada inti sel fibroblas gingiva yang berwarna coklat (Gambar 2). Hal tersebut menunjukkan bahwa 
terjadi perbaikan DNA atau apoptosis pada kelompok perlakuan.

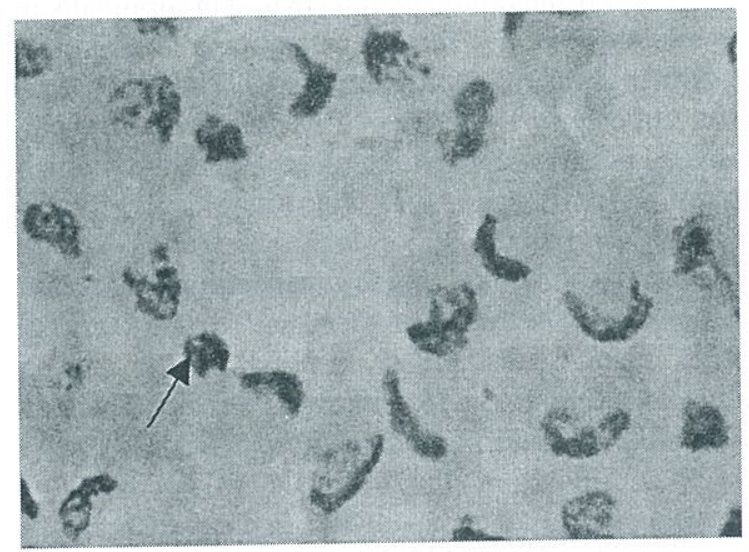

Gambar 1. Pada kelompok kontrol, tidak ada sel fibroblas gingiva yang terekspresi protein p53. Inti sel tidak berwarna coklat (400x)

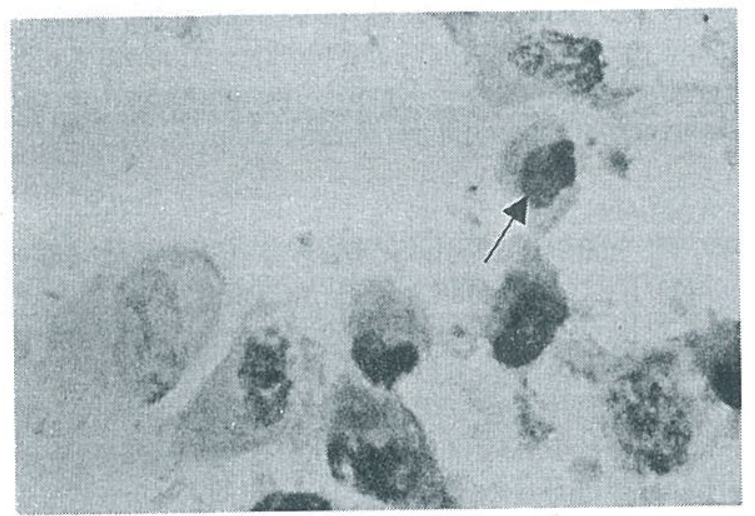

Gambar 2. Pada kelompok perlakuan konsentrasi LPS 50 $\mu \mathrm{g} / \mathrm{ml}$ dengan waktu pajanan $24 \mathrm{jam}$, sel fibroblas gingiva terekspresi protein $\mathrm{p} 53$. Inti sel berwarna coklat $(400 \mathrm{x})$

Hasil penghitungan sel dinyatakan dalam bentuk persentase ekspresi protein p53. Rerata persentase ekspresi protein p53 untuk tiap kelompok sampel dapat dilihat pada Tabel 1.

Rerata ekspresi protein p53 pada konsentrasi LPS 50 dan $200 \mu \mathrm{g} / \mathrm{ml}$ berbeda secara nyata dengan kontrol $(p<0,05)$. Rerata ekspresi protein $p 53$ pada waktu pajanan LPS 24 jam berbeda secara nyata dengan waktu pajanan 48 jam $(\mathrm{p}<0,05)$. Pada uji interaksi menunjukkan probabilitas $0,000(p<0.05)$, maka terdapat interaksi antara kelompok konsentrasi dan waktu pajanan LPS terhadap ekspresi protein p53 pada kultur sel fibroblas gingiva manusia.
Tabel 1. Rerata Persentase Ekspresi protein p53 dan Ki-67

\begin{tabular}{lcc}
\hline $\begin{array}{c}\text { Konsentrasi } \\
(\mu \mathrm{g} / \mathrm{ml})\end{array}$ & $\begin{array}{c}\text { Waktu } \\
(\mathrm{Jam})\end{array}$ & $\begin{array}{c}\text { Ekspresi p53 } \\
(\text { Rerata } \pm \mathrm{SD})\end{array}$ \\
\hline Kontrol & 24 & $0 \pm 0$ \\
& 48 & $0 \pm 0$ \\
LPS 50 & 24 & $81,71 \pm 8,56$ \\
& 48 & $32,15 \pm 6,11$ \\
LPS 200 & 24 & $88,80 \pm 6,61$ \\
& 48 & $21,13 \pm 3,97$ \\
\hline
\end{tabular}

\section{Pembahasan}

Lipolisakarida merupakan suatu komponen struktural dari selaput luar bakteri gram negatif. LPS dapat dideteksi pada plak gigi ${ }^{9}$ dan permukaan akar gigi. ${ }^{3}$ Walaupun LPS merupakan agen inflamatoris yang kuat dan berperan penting pada penyakit periodontal inflamatoris, tetapi LPS juga mempunyai efek sitotoksik secara langsung pada sel-sel periodonsium.,

Hasil penelitian ini menunjukkan bahwa terdapat perbedaan pengaruh pajanan LPS konsentrasi 50 dan $200 \mu \mathrm{g} / \mathrm{ml}$ dengan waktu pajanan 24 dan 48 jam terhadap ekspresi protein p53 pada kultur sel fibroblas gingiva manusia. Pada uji interaksi menunjukkan terdapat interaksi antara kelompok konsentrasi dan waktu pajanan LPS terhadap ekspresi protein p53 pada kultur sel fibroblas gingiva manusia.

Pada Tabel 1 menunjukkan bahwa pajanan LPS konsentrasi 50 dan $200 \mu \mathrm{g} / \mathrm{ml}$ pada hari pertama inkubasi (24 jam) terjadi upregulation dari p53 wild type yang merupakan konsekuensi dari kerusakan DNA, sehingga protein p53 menginduksi penghentian sementara siklus sel agar menyediakan waktu yang cukup untuk perbaikan kerusakan. Jika tidak mungkin terjadi perbaikan, p53 mempromotori apoptosis untuk mengeliminasi sel fibroblas yang rusak karena pajanan LPS. Hasil penelitian di atas menunjukkan bahwa kultur sel fibroblas gingiva pada kelompok perlakuan di awal inkubasi mengalami apoptosis dan perbaikan DNA. Apoptosis sel fibroblas gingiva tersebut merupakan suatu mekanisme sel untuk mengatur pertumbuhan, diferensiasi, dan turnover sel.

$\mathrm{King}^{7}$ berpendapat bahwa pajanan bahan yang bersifat sitotoksik dapat mengakibatkan kerusakan 
sel. Untuk mencegah akibat yang tidak diinginkan, sel mempunyai metode untuk mendeteksi kerusakan DNA dan tindakan bunuh diri. Kerusakan DNA tersebut dapat dideteksi oleh protein p53. Setelah protein p 53 menghentikan siklus sel maka kerusakan dapat diperbaiki atau dapat memicu apoptosis dan kematian sel. Protein p53 berinteraksi dengan sejumlah besar protein sel dan berintegrasi dengan banyak sinyal yang mengontrol hidup dan mati sel. ${ }^{8}$ Oleh karena itu kerusakan DNA akibat pajanan LPS dapat dideteksi oleh protein p53, sehingga sel fibroblas gingiva yang hidup dapat melanjutkan proliferasi dan kerusakan DNA tidak diturunkan pada sel anak.

Protein p53 memegang peranan dalam sintesis, perbaikan DNA dan apoptosis. Protein p53 bereaksi sebagai faktor transkripsi untuk beberapa gen, misalnya p53 menghambat proliferasi dengan menginduksi p21 (cyclin-dependent kinase inhibitor), p53 menstimulasi perbaikan DNA dan p53 mempromotori apoptosis dengan meningkatkan bax dan menurunkan $b c l 2 .^{7}$ Jadi kerusakan DNA dapat diperbaiki dengan perubahan koordinasi antara proliferasi, perbaikan DNA dan apoptosis, sehingga dihasilkan sel-sel anak yang normal pada saat mitosis.

\section{Kesimpulan}

Berdasarkan hasil penelitian yang telah dilakukan pada kultur sel fibroblas gingiva manusia, maka dapat disimpulkan bahwa ekspresi protein p53 yang berlebihan pada waktu pajanan LPS 24 jam menunjukkan bahwa banyak sel fibroblas gingiva yang mengalami kerusakan DNA.

\section{Daftar Pustaka}

1. Haake SK. Periodontal microbiology in Carranza, FA, Newman MG. Clinical Periodontology. $8^{\text {th }}$ ed. WB Saunders Company. Philadelphia: 1996; 84-103.

2. Milier CH. Periodontal microbiology, in Willet NP, White RR, Rosen S. Essential Dental Microbiology. Appleton \& Lange. Connecticut. 1991; 357-71.

3. Olson RH, Adams DF, Layman DL. Inhibitory effects of periodontally diseased root extracts on the growth of human gingival fibroblasts. J Periodontol 1985; 56: 592-6.

4. DeRenzis FA, Chen SY. Ultrastructural study of cultured human gingival fibroblasts exposed to endotoxin. J Periodontol 1983; 54: 86-90.

5. Layman DL., Diedrich DL. Growth inhibitory effects of endotoxins from Bacteroides gingivalis and intermedius on human gingival fibroblast in vitro. $J$ Periodontol 1987; 58: 387-92.

6. Takata T, Miyauchi M, Ogawa I, Ito H, Kobayashi J, Nikai H. 1997. Reactive change in proliferative activity of the junctional epithelium after topical application of lipopolysaccharide. $J$ Periodontol ; 68: 531-5.

7. King RJB. Cancer Biology. $2^{\text {nd }}$ ed. Pearson Education. England. 2000;146-73.

8. Vogelstein B, Lane D, Levine AJ. Surfing the p53 network. Nature 2000; 408:307-10.

9. Duguid R. Inhibition of ${ }^{3} \mathrm{H}$-thymidine uptake in human gingival fibroblasts by extracts from human dental plaque, oral bacteria of the Streptococcus and Actinomyces species. Arch Oral Biol 1985;30:89-93. 